\title{
Discrimination of drought tolerance in a worldwide collection of safflow- er (Carthamus tinctorius L.) genotypes based on selection indices
}

\author{
Pooran GOLKAR ${ }^{1,2,3}$, Esmaeil HAMZEH ${ }^{4}$, Seyed Ali Mohammad MIRMOHAMMADY MAIBODY ${ }^{4}$
}

Received May 11, 2020; accepted February 28, 2021.

Delo je prispelo 11. maja 2020, sprejeto 28. februarja 2021.

Discrimination of drought tolerance in a worldwide collection of safflower (Carthamus tinctorius L.) genotypes based on selection indices

Abstract: Improvement of elite safflower genotypes for drought-tolerance is hampered by a deficiency of effective selection criteria. The present study evaluated 100 genotypes of safflower in terms of their drought tolerance over a period of three years (2016-2018) under both non-stress and droughtstress conditions. The eight drought-tolerance indices of tolerance index (TOL), mean productivity (MP), geometric mean productivity (GMP), stress susceptibility index (SSI), stress tolerance index (STI), yield stability index (YSI), drought resistance index (DI), and harmonic mean (HARM) were calculated based on seed yield under drought $\left(\mathrm{Y}_{\mathrm{s}}\right)$ and non-drought $\left(Y_{p}\right)$ conditions. A high genetic variation was found in drought tolerance among the genotypes studied. The MP, GMP, and STI indices were able to discriminate between tolerant and drought-sensitive genotypes. Plots of the first and second principal components identified drought-tolerant genotypes averaged over the three study years. Cluster analysis divided the genotypes into three distinct groups using the drought tolerance indices. Ultimately, eight genotypes (namely, $G_{3}, G_{11}, G_{13}$, $G_{24}, G_{33}, G_{47}, G_{58}$, and $G_{61}$ ) from different origins were detected as more tolerant to drought stress suitable for use in safflower breeding programs in drought-affected areas. The most tolerant and susceptible genotypes could be exploited to produce mapping populations for drought tolerance breeding programs in safflower.

Key words: cluster analysis; drought stress; principal component analysis; selection index; yield; safflower

Abbreviations: TOL: Tolerance; MP: mean productivity; SSI: drought susceptibility index GMP: geometric mean productivity; YSI: yield stability index; DI: drought resistance index.
Odkrivanje tolerance na sušo v mednarodni zbirki genotipov žafranike (Carthamus tinctorius L.) na osnovi izbranih indeksov

Izvleček: Izboljšanje elitnih genotipov žafranike na prenašanje suše ovira pomanjkanje učinkovitih selekcijskih kriterijev. $\mathrm{V}$ raziskavi je bilo ovrednoteno 100 genotipov žafranike glede na njihovo prenašanje suše $\mathrm{v}$ obdobju treh let (2016-2018) v razmerah brez stresa in razmerah sušnega stresa. Izračunanih je bilo osem indeksov tolerance na sušni stres kot so tolernca na stres (TOL), poprečna produktivnost (MP), geometrijska poprečna produktivnost (GMP), indeks stresne občutljivosti (SSI), indeks stresne tolerance (STI), indeks stabilnosti pridelka (YSI), indeks odpornosti na sušo (DI), in harmonično poprečje na osnovi pridelka semena $\mathrm{v}$ sušnih $\left(\mathrm{Y}_{\mathrm{s}}\right)$ in nesušnih $\left(\mathrm{Y}_{\mathrm{p}}\right)$ razmerah. Med preučevanimi genotipi je bila ugotovljena velika genetska variabilnost v toleranci na sušo. $\mathrm{Z}$ indeksi MP, GMP, in STI je bilo mogoče razlikovati na sušo tolerantne in občutljive genotipe. Polja prve in druge glavne komponente so določila na sušo tolerantne genotipe $\mathrm{v}$ vseh treh letih raziskave. Klasterska analiza je $\mathrm{z}$ uporabo indeksov tolerance na sušo razdelila genotipe v tri jasno ločene skupine. Na koncu je bilo ugotovljenih osem genotipov $\left(G_{3}, G_{11}, G_{13}, G_{24}, G_{33}, G_{47}, G_{58}\right.$, in $\left.G_{61}\right)$ različnega izvora, ki so bili bolj tolerantni na sušo in so primerni za uporabo v žlahtniteljskih programih žafranike na od suše ogroženih območjih. Na sušo najbolj prilagojene genotipe žafranike bi lahko uporabili za odkrivanje populacij, ki bi bile primerne pri žlatnjenju žafranike na sušo.

Ključne besede: klasterska analiza; sušni stres; analiza glavnih komponent; selekcijski indeks; pridelek; žafranika

Okrajšave: TOL: toleranca; MP: poprečna produktivnost; SSI: indeks občutljivosti na sušo; GMP: geometrijska poprečna produktivnost; YSI: indeks stabilnosti pridelka; DI: indeks odpornosti na sušo.

Isfahan University of Technology, Department of Natural Resources, Isfahan, Iran

2 Isfahan University of Technology, Research Institute for Biotechnology and Bioengineering, Isfahan, Iran

3 Corresponding author, e-mail: poorangolkar@gmail.com; golkar@cc.iut.ac.ir

4 Isfahan University of Technology, College of Agriculture, Department of Agronomy and Plant Breeding, Isfahan, Iran 


\section{INTRODUCTION}

Droughts due to alterations in rainfall patterns and climate change form a most devastating factor in food production on a global scale (Blum, 2018; Anjum et al., 2017). This warrants a Blue Revolution in agriculture concentrated on increasing productivity per unit of water to produce more crops per drop of water. Recently, an important target in crop breeding programs is the development of droughttolerant genotypes that possess a high capability for adaption to arid and semi- arid climates (Kirigwi et al., 2004; Basu et al., 2016).

The challenges in understanding the mechanisms involved in plant behavior under water scarcity include: 1 ) mutagenic control of drought tolerance, 2) genetic variability and differences among species in responding to changes in water availability, and 3) interactions with other factors such as drought stress duration and intensity (Varshney et al., 2018). Moreover, breeding programs are adversely affected by the high interaction of genotype $\times$ environment, low heritability of drought tolerance traits, lack of efficient selection particularly under field conditions, and the difficulties associated with simultaneous selection, sharp climate changes, and unpredictable rainfall in different regions (Ashraf, 2010; Rauf et al., 2016; Blum, 2018). Since the genotypes with a high yield under optimum conditions may not be drought tolerant (Blum, 2018), many studies preferred selection under both stress and non-stress conditions (Fernandez, 1992).
To have a high and durable yield in a drought-prone environment drought-tolerant genotypes are needed (Abdolshahi et al., 2012). The capacity of genotypes to perform reasonably well in drought-stressed environments is the paramount reason for their stable production (Raman et al., 2012). To decrease the impacts of abiotic stress without any substantial yield loss, researchers tend to develop drought-tolerant genotypes based on prior evaluation and identification of drought-tolerant germplasm. The high cost of drought soil amelioration has encouraged breeders to use selection indices as an economic and efficient method for resolving the problems associated with drought stress breeding (Vieira et al., 2016).

In this regard, a variety of selection indices to identify stress-tolerant cultivars have been proposed that some of the important and most applicable of them include: Tolerance (TOL) (Rosielle \$ Hamblin, 1981) (Table 1), mean productivity (MP) (Rosielle \& Hamblin, 1981) (See Table 1), stress susceptibility index (SSI) (Fischer and Maurer, 1978) (See Table 1), geometric mean productivity (GMP) (Kristin et al., 1997) (See Table 1), stress tolerance index (STI) (Fernandez, 1992) (See Table 1), yield stability index (YSI) (Gavuzzi et al., 1997) (See Table 1), and drought resistance index (DI) (Lan, 1998) (See Table 1). Our literature review have reported on the efficiency of different selection indices for selecting drought-tolerant genotypes in different crops as like as rice (Raman et al., 2012); canola (Khalili et al., 2012);sunflower (Gholinezhad et al., 2014); maize (Hao et al., 2011) and bread wheat (Abdolshahi et al., 2012).

Safflower (Carthamus tinctorius L.) is an annual oil

Table 1: Different drought tolerance indices used for screening safflower genotypes

\begin{tabular}{|c|c|c|}
\hline Index name & Equations & Reference \\
\hline Mean productivity & $M P=\frac{Y_{s}+Y_{p}}{2}$ & Rosielle and Hamblin, 1981 \\
\hline Tolerance index (TOL) & $T O L=Y p-Y s$ & Ficsher and Maurer, 1978 \\
\hline Geometric Mean Productivity (GMP) & $G M P=\sqrt{(Y p)(Y s)}$ & Kristin et al., 1997 \\
\hline Stress Susceptibility Index (SSI) & $S S I=\frac{1-\left(\frac{Y S}{\bar{Y} p}\right)}{1-\left(\frac{\bar{Y} S}{\bar{Y} p}\right)}$ & Rosielle and Hamblin, 1981 \\
\hline Stress Tolerance Index (STI) & $S T I=\frac{Y S \times Y p}{\bar{Y} p^{2}}$ & Fernandez, 1992 \\
\hline Yield Stability Index (YSI) & $Y S I=\frac{Y S}{\bar{Y}_{P}}$ & Gavuzzi et al., 1997 \\
\hline Drought Resistance Index (DI) & $D I=\frac{Y s \times\left(\frac{Y s}{Y p}\right)}{\bar{Y} s}$ & Lan, 1998 \\
\hline Harmonic Mean & HARM $=2\left(Y_{P} \times Y_{s}\right) /\left(Y_{p}+Y_{s}\right)$ & Kristin et al., 1997 \\
\hline
\end{tabular}


seed crop with diverse industrial and pharmaceutical application that is grown commercially in Iran (Golkar \& Karimi, 2019). The deep roots of safflower make it a droughttolerant plant viable under the drought stress conditions in arid climates (Mirzahashemi et al., 2014; Hussain et al., 2016).

Drought stress is one of the most devastating abiotic stresses that poses a serious threat to worldwide safflower production (Hussain et al., 2016). Given the declining water resources in the arid and semi- arid regions of the world due to consecutive droughts, increased safflower cultivation can be an economic and valuable alternative to other droughttolerant genotypes. In this regards, some studies is known about drought tolerance of local Iranian cultivars (Omidi et al., 2012; Bahrami et al., 2014; Mirzahashemi et al., 2014). Despite of current efforts intended for assessing tolerance criteria based on tolerance indices in safflower, little has been reported at maturity (Bahrami et al., 2014). Furthermore, this tolerance undoubtedly appears to be stage-dependent and must be evaluated at the yielding phase.

Variations in drought patterns such as differences in location, year, and drought intensity as well as genotypic differences call for safflower genotypes with different levels of drought tolerance to be cultivated in different areas. However, the differences in the genotypes recommended might have stemmed from the variability in the drought tolerance potential of safflower genotypes. Moreover, climate changes increase drought frequency in some regions but drought is a global issue. Given the broad distribution of safflower around the world, it is the objective of the present study to identify drought-tolerant genotypes from a new worldwide collection based on drought selection indices. The new identified genotypes could be used for cultivation in arid regions of the world.

\section{MATERIALS AND METHODS}

\subsection{PLANT MATERIAL}

One hundred safflower genotypes originating from different geographical regions of the world were selected for screening drought tolerance (Table S1). The exotic genotypes were obtained from Leibniz Institute of Plant Genetics and Crop Plant Research (IPK), Germany. Iranian genotypes were taken from the genotype inventory at the Agricultural Research Center, Isfahan, Iran.

\subsection{FIELD EXPERIMENT AND IRRIGATION RE- GIMES}

An experiment was carried out in three consecutive years from early March 2016 to the end of 2018 at Lavark Research Farm, affiliated to Isfahan University of Technology, $40 \mathrm{Km}$ southwest of Isfahan $\left(32^{\circ} 32^{\prime} \mathrm{N}, 51^{\circ} 23^{\prime} \mathrm{E}\right.$, $1630 \mathrm{~m}$ above sea level), Iran. Mean annual precipitation and temperature at this site are $149 \mathrm{~mm}$ and $15.4^{\circ} \mathrm{C}$, respectively. The soil was silty clay loam with a bulk density of $1.3 \mathrm{~g} \mathrm{~cm}^{-3}$ in the top $50 \mathrm{~cm}$ and a $\mathrm{pH}$ level of 7.4-7.9. The field experimental design was a square lattice design (10 by 10) with two replications for each different irrigation (drought stress and non-drought) regimes in each year. The seeds were planted in rows of $3 \mathrm{~m}$ long and spaced $25 \mathrm{~cm}$ from each other to yield a plant density of 40 plants $\mathrm{m}^{-2}$ in the plots. All the plants received the first irrigation before planting. After this period, irrigation was applied every week until the budding stage. From budding stage to full maturity stage, the non-stress treatment involved irrigation when $50 \%$ of the total available water was depleted from the root zone, but in the drought stress conditions, irrigation was applied when $85 \%$ of the total available water was depleted from the root zone.

The irrigation interval (number of days between two irrigations) during the growing season (budding to full maturity) was variable because of the variation in evapotranspiration (ET). Soil samples were taken from a depth of 0 to $60 \mathrm{~cm}$ of the soil from both drought and non- drought plots to determine the soil water content and calculate the irrigation water content on the basis of a $60 \mathrm{~cm}$ rooting depth. Soil samples were taken before each irrigation when evaporation from a Class A pan indicated 70 and $140 \mathrm{~mm}$ of evaporation under normal and drought-stress conditions, respectively.

Then, irrigation depth was determined using the formulae: $\left.\mathrm{I}=\left[\left(\theta_{\mathrm{FC}}-\theta_{\mathrm{i}}\right) / 100\right] \mathrm{D} \times \mathrm{B}\right)$; where, I represents irrigation depth $(\mathrm{cm}), \theta_{\mathrm{FC}}(-0.03 \mathrm{MPa})$ is soil gravimetric moisture percentage at field capacity $(22 \%), \theta \mathrm{i}(-1.5 \mathrm{MPa})$ is soil gravimetric moisture percentage at irrigation time (10\%), $\mathrm{D}$ is root-zone depth $(50 \mathrm{~cm})$, and B is soil bulk density at the root zone $\left(1.3 \mathrm{~g} \mathrm{~cm}^{-3}\right)$ (Clarke et al., 2008). The volume of irrigation water applied was monitored at each irrigation by calculating the depth of water over a Parshall flume which was calculated as: $\mathrm{Id}=\mathrm{I} \times p$, where $p$ is the fraction of I that can be depleted from the root zone. Then $I_{g}=\left(I_{d} /\right.$ $\mathrm{Ea}) \times 100$, which $\mathrm{E}_{\mathrm{a}}$ is irrigation efficiency (\%), assumed to be $65 \%$ on the average. The differences in available water related to different mean for temperature in growing seasons across three years of study. No growth regulators or fungicides were applied. Surface application of $130\left(\mathrm{~kg} \mathrm{ha}^{-1}\right)$ $\mathrm{N}$ and $25\left(\mathrm{~kg} \mathrm{ha}^{-1}\right) \mathrm{P}$ was carried out in both treatments with an additional $55 \mathrm{~kg} \mathrm{ha}^{-1}$ of $\mathrm{N}$ during the rosette stage. Plants were harvested in the middle row at maturity and seed yield was recorded in each plot. Ten different selection indices were calculated using the equations reported in Table 1 . In these equations, $Y_{\mathrm{S}}$ represents the 
yield of genotypes under stress; $Y_{\mathrm{P}}$ the yield of genotypes under normal conditions $\left(\mathrm{kg} \mathrm{ha}^{-1}\right)$; and denote mean yields of all the genotypes under stress and non-stress conditions, respectively.

\subsection{STATISTICAL ANALYSIS}

A combined analysis of variance (ANOVA) was performed using SAS software (SAS. Ver. 9.3.1), for seed yield and selection indices using GLM procedure. Principal Component Analysis (PCA) and 3D biplot diagrams were exploited to identify tolerant and susceptible genotypes using R software (Ver. 3.6.1). Correlations between seed yield in the non-stress and drought-stress treatment as well as the relevant drought tolerance indices were determined using SAS PROC CORR and Heat Map Graph (R software ver 3.6.1). The safflower genotypes were classified using the seed yields obtained from each of the water treatments and drought tolerance indices data using the Ward algorithm based on the squared Euclidean distances in the R Software (Ver. 3.6.1).

\section{RESULTS}

Analysis of variance indicated the non-significant effect of year on all the studied traits (Table 2). A highly significant $(p<0.01)$ variation in seed yield was observed among the studied genotypes under both (stress and nonstress) conditions and for all the tolerance indices examined (Table 2 ). The genotype $\times$ year interaction effect was not significant for any of the indices, except for DI and HARM (Table 2). The significant genotype $\times$ environment interaction for both DI and HARM, indicating considerable variability among the genotypes across different years and different irrigation treatments for these selection indices.

Table 3 reports the ten highest and the lowest seed yields, $Y_{p}$ and $Y_{s}$, for the studied genotypes. Clearly, the highest $Y_{p}$ values were obtained for $G_{13}\left(5680 \mathrm{~kg} \mathrm{ha}^{-1}\right.$ ) (from Iran) and $G_{61}\left(5310 \mathrm{~kg} \mathrm{ha}^{-1}\right.$ ) (from Morocco), but the least $Y_{p}$ value was obtained for $G_{79}\left(900 \mathrm{~kg} \mathrm{ha}^{-1}\right)$. Under stress conditions, the highest seed yield $\left(\mathrm{Y}_{\mathrm{s}}\right)$ was obtained in genotypes $47\left(3038 \mathrm{~kg} \mathrm{ha}^{-1}\right)$ and $24\left(2670 \mathrm{~kg} \mathrm{ha}^{-1}\right)$, but the lowest $\left(590 \mathrm{~kg} \mathrm{ha}^{-1}\right)$ was observed in $\mathrm{G}_{79}$ (Table 3$) . \mathrm{G}_{13}$ recorded the highest values of TOL (4130), SSI (1.61), and HARM (1.14) indices, whereas $\mathrm{G}_{86}$ (from Tajikistan) recorded the least values for TOL (260), SSI (0.24), and HARM (0.13). The highest (0.87) and the lowest (0.27) values of YSI were obtained for $G_{86}$ and $G_{13}$, respectively. Finally, the genotypes 47 and 25 had the highest (1.55) and lowest (0.20), respectively, mean values of the DI index (Table 3 ).

The correlation coefficients among $\mathrm{Y}_{\mathrm{p}}, \mathrm{Y}_{\mathrm{s}}$, and other drought tolerance selection indices were calculated to determine the most desirable drought tolerance criteria (Table 4). It was found that seed yield and YSI exhibited negative $\left(-0.5^{* *}\right)$ and positive $\left(0.34^{* *}\right)$ correlations under the non-stress and stress conditions, respectively. Seed yield under the non-stress treatment showed positive and significant correlations with all the selection indices, except for YSI $\left(-0.50^{* *}\right)$ and DI (Table 4$)$. Seed yield under the stress treatment showed positive and significant correlations with MP, GMP, STI, and DI but negative and significant ones with SSI and HARM (Table 4).

Principal Component Analysis (PCA) as a representative for distinguish the relationships among the indices revealed that the first component $\left(\mathrm{PC}_{1}\right)$ explained $54 \%$ of the total seed yield variation and exhibited positive correlations with Yp, MP, GMP, and STI (Figure 1). PC 2 explained $44 \%$ of the total yield variation and had higher positive correlations with DI, YSI, and Ys but higher negative correlations with SSI and HARM (Figure 1).

Table 2: Combined analysis of variance for seed yield under non-stress $\left(\mathrm{Y}_{\mathrm{p}}\right)$ and stress $\left(\mathrm{Y}_{\mathrm{s}}\right)$ conditions and different susceptibility indices in safflower genotypes growing under drought stress and normal conditions evaluated in 2016 and 2018

\begin{tabular}{|c|c|c|c|c|c|c|c|c|c|c|c|}
\hline S.O.V & $\mathrm{DF}$ & $\mathrm{Y}_{\mathrm{P}}$ & Ys & SSI & YSI & TOL & MP & GMP & STI & DI & HARM \\
\hline Year (Y) & 2 & 3947374.2 & 77841 & 0.00019 & 0.05 & 133849.6 & 29145.2 & 303800.5 & 0.047 & 0.34 & 0.2 \\
\hline $\begin{array}{l}\text { Block/ } \\
\text { Year }\end{array}$ & 3 & 282227.2 & 117545.25 & 0.36 & 0.06 & 696640.8 & 25726.0 & 14486.5 & 0.003 & 0.13 & 0.18 \\
\hline $\begin{array}{l}\text { Genotype } \\
\text { (G) }\end{array}$ & 99 & $3305183.4^{* *}$ & $844416.53^{* \times}$ & $0.40^{* *}$ & $0.08^{* *}$ & $2177268.3^{* *}$ & $1530482.9^{* *}$ & $1260048.7^{* *}$ & $0.53^{* *}$ & 0.34 & $0.23^{* *}$ \\
\hline$G \times Y$ & 198 & 89064.9 & 80535.49 & 0.071 & 0.01 & 143568.0 & 48908.2 & 55476.1 & 0.028 & $0.05^{* *}$ & $0.54^{* *}$ \\
\hline Residual & 297 & 89064.9 & 154372.9 & 0.12 & 0.025 & 350774.0 & 122390.6 & 125950.5 & 0.06 & 0.09 & 0.07 \\
\hline
\end{tabular}

${ }^{*}$ and ${ }^{* *}$, significant at $p<0.05$ and $p<0.01$, respectively. Abbreviations: DF: degree of freedom; $Y_{p}$ : seed yield under non-stress; $Y_{s}$ : seed yield under stress; SSI: stress susceptibility index, YSI: yield stability index; TOL: stress tolerance; MP: mean productivity; GMP: geometric mean productivity; STI: stress tolerance index; DI: Drought Resistance Index; and HARM: Harmonic mean 
Table 3: Ten highest and lowest values for seed yield under non-stress conditions ( $\left.\mathrm{Y}_{\mathrm{p}}\right)$, Seed yield under stress conditions (Y $)$, and different selection indices among the 100 different safflower genotypes investigated

\begin{tabular}{|c|c|c|c|c|c|c|c|c|c|c|}
\hline $\begin{array}{l}\text { Ten high } \\
\text { indices }\end{array}$ & $\begin{array}{l}\text { stYP } \\
\left(\mathrm{kg} \mathrm{ha}^{-1}\right)\end{array}$ & $\begin{array}{l}\text { YS } \\
\left(\mathrm{kg} \mathrm{ha}^{-1}\right)\end{array}$ & SSI & YSI & TOL & MP & GMP & STI & DI & HARM \\
\hline & $5680(\mathrm{G} 13)$ & $3080(\mathrm{G} 47)$ & $1.613(\mathrm{G} 13)$ & $0.8724(\mathrm{G} 86)$ & $4130(\mathrm{G} 13)$ & 3985(G47) & $3820.2(\mathrm{G} 47)$ & $2.2172(\mathrm{G} 47)$ & $1.5516(\mathrm{G} 47)$ & $1.1488(\mathrm{G} 13)$ \\
\hline & $5310(\mathrm{G} 61)$ & $2670(\mathrm{G} 24)$ & $1.58(\mathrm{G} 61)$ & 0.8552 (G50) & $3770(\mathrm{G} 61)$ & 3615 (G13) & $3233.2(\mathrm{G} 24)$ & $1.6356(\mathrm{G} 11)$ & $1.3097(\mathrm{G} 24)$ & $1.1104(\mathrm{G} 61)$ \\
\hline & 4910(G58) & $2390(\mathrm{G} 11)$ & $1.5697(\mathrm{G} 25)$ & $0.84(\mathrm{G} 99)$ & $3140(\mathrm{G} 58)$ & $3425(\mathrm{G} 61)$ & $3159.8(\mathrm{G} 11)$ & $1.5709(\mathrm{G} 24)$ & $1.1934(\mathrm{G} 94)$ & $1.1069(\mathrm{G} 76)$ \\
\hline & $4890(\mathrm{G} 47)$ & 2385(G3) & $1.5629(\mathrm{G} 76)$ & 0.8148 (G38) & $2800(\mathrm{G} 76)$ & $3380(\mathrm{G} 11)$ & $3046.4(\mathrm{G} 3)$ & $1.4443(\mathrm{G} 3)$ & 1.1672(G97) & $1.1029(\mathrm{G} 25)$ \\
\hline & $4520(\mathrm{G} 33)$ & 2350(G97) & $1.5285(\mathrm{G} 18)$ & 0.8042 (G81) & $2760(\mathrm{G} 33)$ & $3340(\mathrm{G} 58)$ & 2957.2(G13) & $1.33(\mathrm{G} 13)$ & $1.15(\mathrm{G} 69)$ & $1.0677(\mathrm{G} 18)$ \\
\hline & $4370(\mathrm{G} 11)$ & 2167.5(G48) & $1.5057(G 59)$ & 0.7948 (G94) & $2750(\mathrm{G} 18)$ & $3305(\mathrm{G} 24)$ & 2931(G58) & 1.2916 (G58) & $1.1144(\mathrm{G} 48)$ & 1.03 (G59) \\
\hline & $3980(\mathrm{G} 27)$ & $2160(\mathrm{G} 2)$ & $1.4701(\mathrm{G} 27)$ & 0.7841 (G41) & $2690(\mathrm{G} 27)$ & $3142.5(\mathrm{G} 3)$ & 2846.3(G61) & $1.2356(\mathrm{G} 61)$ & 1.1077(G99) & $1.0095(\mathrm{G} 27)$ \\
\hline & $3980(\mathrm{G} 18)$ & $2130(\mathrm{G} 63)$ & 1.4483(G66) & 0.7749 (G12) & 2450 (G59) & $3140(\mathrm{G} 33)$ & 2824.3(G97) & 1.215 (G97) & $1.0974(\mathrm{G} 63)$ & $0.9724(\mathrm{G} 66)$ \\
\hline & $3940(\mathrm{G} 24)$ & 2118.3(G94) & $1.4284(\mathrm{G} 58)$ & $0.7713(\mathrm{G} 69)$ & $2440(\mathrm{G} 25)$ & 2880(G97) & 2817.8(G33) & $1.2063(\mathrm{G} 33)$ & $1.0941(\mathrm{G} 86)$ & $0.97(\mathrm{G} 21)$ \\
\hline & $3900(\mathrm{G} 3)$ & 2100(G69) & $1.4258(\mathrm{G} 21)$ & $0.7668(\mathrm{G} 37)$ & 2300(G66) & 2845(G2) & 2759(G2) & $1.1386(\mathrm{G} 2)$ & 1.0793(G11) & 0.9508 (G58) \\
\hline $\begin{array}{l}\text { Ten lowest } \\
\text { indices }\end{array}$ & $\begin{array}{l}\mathrm{Y}_{\mathrm{p}} \\
\left(\mathrm{kg} \mathrm{ha}^{-1}\right)\end{array}$ & $\begin{array}{l}Y_{\mathrm{S}} \\
\left(\mathrm{kg} \mathrm{ha}^{-1}\right)\end{array}$ & SSI & YSI & TOL & MP & G & $\mathrm{S}$ & DI & M \\
\hline 1 & 2660(G8) & $930(\mathrm{G} 78)$ & $1.3358(G 95)$ & 0.7411 (G10) & 1915(G39) & 2660 (G57) & 2568.3(G48) & $1.0026(\mathrm{G} 48)$ & $1.0463(\mathrm{G} 96)$ & 0.8926 (G95) \\
\hline 2 & 1510(G81) & 920(G95) & $0.5084(\mathrm{G} 69)$ & $0.3546(\mathrm{G} 21)$ & $410(\mathrm{G} 71)$ & $1210(\mathrm{G} 67)$ & 1167.2(G64) & $0.209(\mathrm{G} 31)$ & $0.3026(\mathrm{G} 79)$ & $0.2604(\mathrm{G} 69)$ \\
\hline 3 & $1460(\mathrm{G} 64)$ & 920 (G87) & $0.4939(\mathrm{G} 12)$ & $0.3461(\mathrm{G} 66)$ & 380(G99) & $1200(\mathrm{G} 64)$ & 1161.3(G31) & $0.2038(\mathrm{G} 64)$ & 0.3007 (G95) & $0.2553(\mathrm{G} 12)$ \\
\hline 4 & $1450(\mathrm{G} 67)$ & $910(\mathrm{G} 37)$ & $0.4824(\mathrm{G} 41)$ & $0.3334(\mathrm{G} 27)$ & 340(G38) & $1175(\mathrm{G} 71)$ & $1155.7(\mathrm{G} 71)$ & $0.2032(\mathrm{G} 71)$ & $0.3003(\mathrm{G} 66)$ & $0.2536(\mathrm{G} 41)$ \\
\hline 5 & 1380(G89) & $890(\mathrm{G} 21)$ & $0.4545(\mathrm{G} 94)$ & 0.3204 (G59) & $339(\mathrm{G} 5)$ & $1160(\mathrm{G} 89)$ & 1138.2(G89) & 0.1942 (G89) & $0.2884(\mathrm{G} 18)$ & 0.2367 (G94) \\
\hline 6 & $1380(\mathrm{G} 71)$ & $860(\mathrm{G} 31)$ & $0.4392(\mathrm{G} 81)$ & 0.3093 (G18) & $320(\mathrm{G} 81)$ & 1150(G9) & 1071.8(G9) & 0.173 (G9) & $0.2834(\mathrm{G} 87)$ & $0.2299(\mathrm{G} 81)$ \\
\hline 7 & $1350(\mathrm{G} 82)$ & $801(G 5)$ & $0.4147(\mathrm{G} 38)$ & $0.2939(G 76)$ & $310(\mathrm{G} 79)$ & $1070(\mathrm{G} 82)$ & 1046.6(G37) & $0.1647(\mathrm{G} 37)$ & 0.2647 (G59) & $0.208(\mathrm{G} 38)$ \\
\hline 8 & $1210(\mathrm{G} 37)$ & 790(G82) & 0.3429 (G99) & $0.2904(\mathrm{G} 25)$ & $300(\mathrm{G} 50)$ & $1060(\mathrm{G} 37)$ & $1026(\mathrm{G} 82)$ & $0.1582(\mathrm{G} 82)$ & $0.2497(\mathrm{G} 21)$ & 0.1803 (G99) \\
\hline 9 & 1140(G5) & 780(G9) & $0.3284(G 50)$ & $0.2884(\mathrm{G} 61)$ & 300(G37) & $970.5(G 5)$ & $952.4(\mathrm{G} 5)$ & $0.1363(G 5)$ & $0.2346(\mathrm{G} 76)$ & $0.1587(\mathrm{G} 50)$ \\
\hline 10 & 900 (G79) & $590(G 79)$ & $0.2846(G 86)$ & 0.2719 (G13) & 260(G86) & 745(G79) & 718.9(G79) & 0.0788 (G79) & $0.2024(\mathrm{G} 25)$ & 0.1392 (G86) \\
\hline
\end{tabular}

Table 4: Correlation coefficients between seed yield $\left(\mathrm{kg} \mathrm{ha}^{-1}\right)$ of safflower genotypes under non-stress (Yp) and stress (Ys) conditions and each of the stress susceptibility indices averaged over three years

\begin{tabular}{|c|c|c|c|c|c|c|c|c|c|c|}
\hline & $Y_{p}$ & $\mathrm{Y}_{\mathrm{s}}$ & SSI & YSI & TOL & MP & GMP & STI & HARM & DI \\
\hline$Y_{p}^{q}$ & 1 & & & & & & & & & \\
\hline$Y_{s}$ & $0.59^{* *}$ & 1 & & & & & & & & \\
\hline SSI & $0.50^{* *}$ & $-0.34^{* *}$ & 1 & & & & & & & \\
\hline YSI & $-0.50^{* *}$ & $0.34^{* *}$ & $-0.99^{* *}$ & 1 & & & & & & \\
\hline TOL & $0.86^{* *}$ & 0.10 & $0.83^{* *}$ & $-0.83^{* *}$ & 1 & & & & & \\
\hline MP & $0.95^{* *}$ & $0.80^{* *}$ & $0.24^{*}$ & $-0.24^{*}$ & $0.67^{* *}$ & 1 & & & & \\
\hline GMP & $0.88^{* *}$ & $0.89^{* *}$ & 0.08 & -0.08 & $0.52^{* *}$ & $0.98^{* *}$ & 1 & & & \\
\hline STI & $0.86^{* *}$ & $0.88^{* *}$ & 0.06 & -0.06 & $0.50^{* *}$ & $0.96^{* *}$ & $0.98^{* *}$ & 1 & & \\
\hline HARM & $0.53^{* *}$ & $-0.32^{* *}$ & $0.99^{* *}$ & $-0.99^{* *}$ & $0.86^{* *}$ & $0.27^{* *}$ & 0.10 & 0.08 & 1 & \\
\hline DI & 0.17 & $0.89^{* *}$ & $-0.70^{* *}$ & $0.70^{* *}$ & $-0.31^{* *}$ & $0.47^{* *}$ & $0.61^{* *}$ & $0.61^{* *}$ & $-0.67^{\star *}$ & 1 \\
\hline
\end{tabular}

${ }^{*}$ and ${ }^{* *}$ Significant at $p<0.05$ and $p<0.01$; respectively; ns, not significant.

Abbreviations $¥: Y_{p}$ : Seed yield under non- stress condition; $Y_{s}$ : Seed yield under stress condition; SSI: stress susceptibility index, YSI: yield stability index, TOL: stress tolerance, MP: mean productivity, GMP: geometric mean productivity, STI: stress tolerance index, HARM: harmonic mean, DI: drought resistance index. 


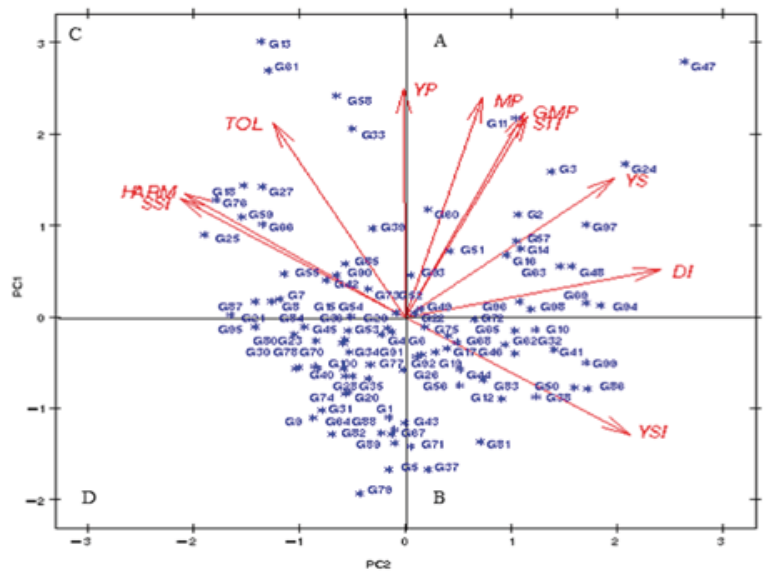

Figure 1: Biplot drawn based on the first and second components obtained from principal component analysis using seed yield of safflower genotypes under non stress $\left(\mathrm{Y}_{\mathrm{p}}\right)$ and stress $\left(\mathrm{Y}_{\mathrm{s}}\right)$ conditions. Abbreviations: stress susceptibility index (SSI), yield stability index (YSI), stress tolerance (TOL), mean productivity (MP), geometric mean productivity (GMP), stress tolerance index (STI), drought resistance index (DI); harmonic mean (HARM), and conditions in 100 safflower genotypes.

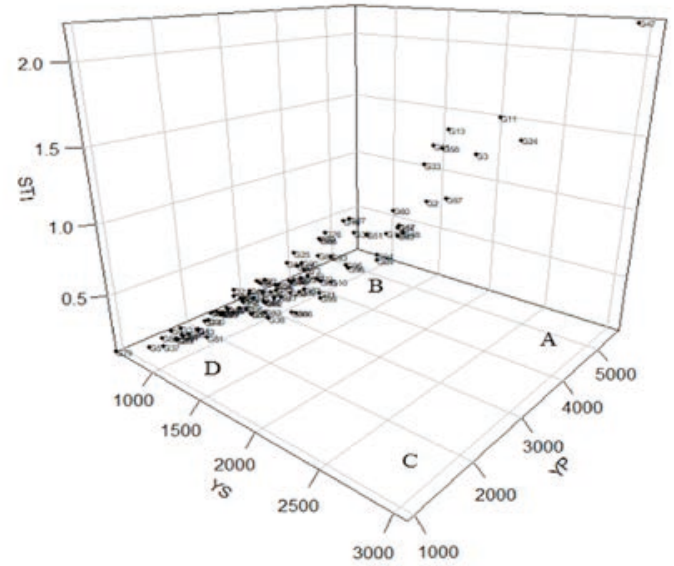

Figure 2: Three-dimensional diagram for identifying drought-tolerant genotypes based on seed yield under non-stress ( $\left.\mathrm{Y}_{\mathrm{p}}\right)$ and stress $\left(\mathrm{Y}_{\mathrm{s}}\right)$ conditions as well as the stress tolerance index (STI).

Because of the positive and significant correlation of STI with seed yield under both conditions, a threedimensional graphs based on the STI index were drawn (Figure 2). These graphs split the genotypes into four groups, each of which represents one combination of the genotypes. The genotypes 47, 24, 97, 3, and 11 (Group A) are those with high yields under drought and nonstress environments. Those in Group B (e.g., $\mathrm{G}_{13}, \mathrm{G}_{59}$, and $G_{61}$ ) consisted of genotypes with high yields in a normal environment but low seed yields under drought conditions. No genotype was, however, detected as one with a high yield in a stressful environment (Group C). The genotypes with low yields under both environmental conditions were assigned to Group D (e.g., $G_{3}, G_{11}, G_{79}$, and $\mathrm{G}_{5}$ ).

\subsection{CLUSTER ANALYSIS}

A dendrogram was drawn based on the cluster analysis using seed yield under drought and non-drought conditions along with the selection indices TOL, MP, GMP, STI, SSI, YSI, DI, and HARM (Figure 3). The cluster analysis performed classified the 100 genotypes of safflower investigated into three distinct groups consisting of 7, 44, and 49 genotypes. The genotypes in the smallest group (1) including $G_{13}, G_{61}, G_{33}, G_{58}, G_{47}, G_{11}, G_{24}$, and $\mathrm{G}_{3}$ showed the highest seed yield under both non-stress and drought stress conditions (Figure 3). The genotypes clustered in Group 2 (i.e., $G_{51}, G_{93}, G_{39}, G_{60}, G_{2}, G_{57}, G_{14}$, $G_{16}, G_{97}, G_{48}, G_{63}, G_{99}, G_{50}, G_{86}, G_{10}, G_{65}$, and $G_{81}$ ) recorded medium levels of seed yield under drought stress. The 


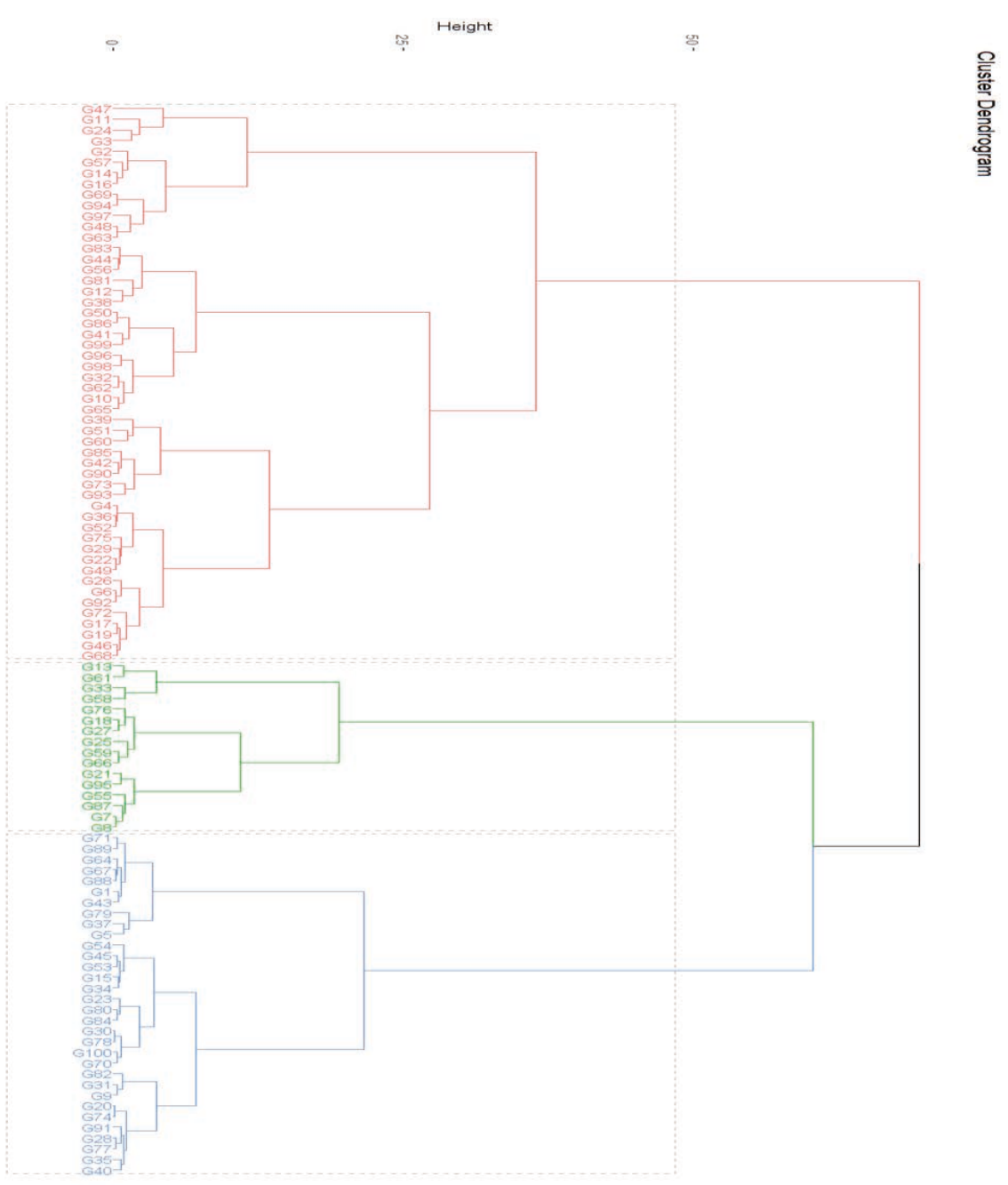

Figure 3: Discrimination of drought tolerance in a worldwide collection of safflower (Carthamus tinctorius L.) genotypes based on selection indices.

third group consisted of genotypes with a low productivity under either environmental conditions (i.e., $G_{79}, G_{37}$, $\mathrm{G}_{89}, \mathrm{G}_{55}, \mathrm{G}_{21}$, and $\mathrm{G}_{25}$ ).

\section{DISCUSSION}

This study evaluated drought tolerance in a world collection of safflower accessions under the effects of year and genotype. The analysis of variance showed a large genetic variation in drought tolerance among the accessions studied as an unpredictable factor affecting seed yield in the genotypes from different geographical regions. Year factor was not found to have any significant effect on seed yield or selection indices; hence, the indi- ces selected for this germplasm can be effectively used if seed yield is adequately heritable. Considering the fact that traits involved in drought tolerance mechanisms are polygenic ones, the requirement to screen tolerant genotypes has encouraged plant breeders to seek a reliable index. In response to this need, the present study evaluated eight different selection indices (i.e., MP, GMP, TOL, SSI, STI, YSI, DI, and HARM) for use in the estimation of seed yield under drought stress. Based on the correlation analysis performed, the positive and significant correlation between TOL and $\mathrm{Y}_{\mathrm{p}}\left(0.86^{* *}\right)$ implies that the genotypes superior in terms of seed yield (such as $G_{79}$ and $G_{9}$ ) showed greater reductions in seed yield under drought conditions. Also, the non-significant correlation between TOL and $Y_{s}(0.10)$ revealed the failure of the TOL index 
to identify the most tolerant genotypes, confirming the results reported by Rizza et al. (2004). The greater TOL values indicated the higher sensitivity of the genotypes investigated to drought stress; thus, smaller values of this index is favored. The positive and significant correlation between $\mathrm{Y}_{\mathrm{p}}$ and SSI $\left(0.50^{* *}\right)$ and that between $\mathrm{Y}_{\mathrm{p}}$ and HARM $\left(0.53^{* *}\right)$ demonstrated that the genotypes with higher values for $\mathrm{Y}_{\mathrm{p}}$ or the SSI index exhibited a higher sensitivity to drought stress (Table 2). On the other hand, the negative and significant correlation between SSI and Ys $\left(-0.34^{* *}\right)$ or that between HARM and $\mathrm{Y}_{\mathrm{s}}\left(-0.32^{* *}\right)$ implied that the superior genotypes under drought stress recorded lower values for SSI and HARM. Hence, the SSI and HARM indices are able to discriminate superior safflower genotypes (the ones with lower values of SSI or HARM indices) in drought prone areas. Studying spring wheat, Guttieri et al. (2001) maintained that SSI values $>1$ and $<1$ might indicate above-average and below-average susceptibility to drought stress, respectively. The most suitable index for selecting stresstolerant genotypes is an index that establishes a positive and strong correlation with seed yield under both stress and non-stress conditions (Fernandez, 1992). To select drought-tolerant genotypes, based on the most desirable indices, use is made of the correlation coefficient of each index with $\mathrm{Y}_{\mathrm{p}}$ and $\mathrm{Y}_{\mathrm{s}}$ (Golabadi et al., 2006; Ebrahymian et al., 2012; Abdolshahi et al., 2012; Naghavi et al., 2013). Seed yield was found to have a highly significant positive correlation with GMP, MP, STI, and HARM indices under both the environmental (drought and non- drought conditions) conditions examined (Table 2). Based on the correlation analysis conducted in this study, GMP, STI, and MP were found to favor genotypes with a high-yield potential under stress conditions (Table 2), which agrees with the findings reported Sio-Se Mardeh et al. (2006), Hao et al. (2011), and Ebrahimiyan et al. (2012). Given the fact that $G_{47}$ recorded the highest values for MP and STI, this genotype was identified as the most productive and stable safflower ones from among the ones investigated under both stress and non-stress conditions. The results of the present study indicating the capability of the selection indices GMP, MP, and STI to identify genotypes satisfactorily under both conditions are consistent with those reported for GMP and MP in mungbean (Fernandez, 1992); STI and GMP in rice (Raman et al., 2012); safflower (Bahrami et al., 2014) Brassica napus L. (Khalili et al., 2012) and durum wheat (Ilker et al., 2011); as well as GMP, STI, and MP in tall fescue (Ebrahymian et al., 2012) and maize (Hao et al., 2011). GMP is often used by plant breeders interested in calculating relative performance since drought stress might vary in severity both under field conditions and over different years (Fernandez, 1992). In the present study, GMP established significant and positive correlations with TOL, $\mathrm{Y}_{\mathrm{p}}$, and $\mathrm{Y}_{\mathrm{s}}$ (Table 3). DI, which is commonly accepted as an index to identify genotypes with high yields under both stress and non-stress conditions (Lan, 1998), showed only a highly significant and positive correlation with $\mathrm{Y}_{s}\left(0.89^{* *}\right)$ (Table 4 ), demonstrating that selection of safflower genotypes with high DI values might be useful for severe droughtstricken regions but that the genotypes selected based on this index do not have very high yields or yields equivalent to those of genotypes currently cultivated under normal irrigation. Seed yield under non-drought conditions (Yp) was positively correlated with $\mathrm{Y}_{\mathrm{S}}$, confirming previous reports on safflower (Bahrami et al., 2014) other crop species such as bread wheat (El-Rawy and Hassan, 2014), corn (Naghavi et al., 2013) and bread wheat (Abdolshahi et al., 2012). It may also be noted that the satisfactory responses shown by some genotypes under stress conditions could be ascribed to the good adaptation mechanisms in these genotypes (Naghavi et al., 2013). The impacts of the different indices in each $\mathrm{PC}$ indicate that $\mathrm{PC}_{1}$ and $\mathrm{PC}_{2}$ could be identified as yield potential and stress susceptibility groups, respectively. The genotypes (such as $G_{47}, G_{11}, G_{3}$, and $G_{24}$ ) recording high values for both $\mathrm{PC}_{1}$ and $\mathrm{PC}_{2}$ may be considered as superior ones for seed yield under both experimental conditions; hence, they are designated as stable genotypes (Figure 1A). The genotypes recording low $\mathrm{PC}_{1}$ but high $\mathrm{PC}_{2}$ values included those also with high values of DI, YSI, and seed yield under drought stress, but low values of SSI and HARM values (Figure $1 \mathrm{~B}$ ). The genotypes (such as $\mathrm{G}_{13}$ and $\mathrm{G}_{61}$ ) recording high $\mathrm{PC}_{1}$ but low $\mathrm{PC}_{2}$ values included genotypes with high values for GMP, STI, MP, and seed yields under non-stress conditions (Figure 1C). On the other hand, the majority of the genotypes with low $\mathrm{PC}_{1}$ and $\mathrm{PC}_{2}$ values were identified as susceptible genotypes; these included $G_{79}$, as the most tolerant one, and the genotypes $\mathrm{G}_{9}, \mathrm{G}_{82}$, and $\mathrm{G}_{89}$ (Figure $1 \mathrm{D}$ ), that were recognized as unstable genotypes. The majority of the genotypes investigated (more than $60 \%$ ) were classified in Groups B and D (Figure 1). This biplot may also be used for identifying contrasting genotypes (genotypes in group A versus D) for planning fine mapping populations for safflower genome studies of drought tolerance. Based on our cluster analysis, the genotypes assigned to Group 3 were recognized as the most tolerant ones to be used as parents for improving drought tolerance in safflower breeding programs. Thus, the genotypes in Group 1 and Group 3 were identified as drought tolerant and drought susceptible, respectively. Cluster analysis has been widely used not only to discriminate high distance genotypes but also to determine genetic diversity based on similar traits under drought stress conditions (Golabadi et al., 2006; Mohammadi et al., 2011; Naghavi et al., 2013). The results of the 
present cluster analysis of the genotypes investigated were consistent with the PCA results obtained. Thus, droughttolerant genotypes recording high $\mathrm{PC}_{1}$ and $\mathrm{PC}_{2}$ values as well as those assigned to Groups of 1 and 3 in the cluster analysis can be used as extreme parental genotypes with the highest genetic distance to develop new hybrid varieties in safflower aimed at production of drought-tolerant cultivars. However, further evaluation of genotypes using drought tolerance indices across multiple locations is required to confirm their stability for developing improved safflower genotypes.

\section{CONCLUSION}

From the results obtained, it may be concluded that it is preferable to use simultaneously different drought tolerance indices for screening drought-tolerant safflower genotypes. The results of different multivariate analyses revealed that STI, MP, and GMP, in this descending order, were not only capable of efficient selection of high seed-yield genotypes under both the environmental conditions examined but also of discrete identification of drought-tolerant from drought-sensitive safflower genotypes. The $\mathrm{G}_{47}$ genotype (Spanish origin) was identified as the most drought-tolerant one with the highest seed yield under both drought and non-stress conditions. Based on the results obtained in this study, the elite genotypes (i.e., $G_{24}, G_{13}, G_{3}, G_{11}, G_{33}, G_{58}$, and $G_{61}$ ) may be recommended as promising cultivars for cultivation in drought-affected areas or as appropriate donor parents in safflower hybridization programs. These genotypes may also be exploited for improving seed yield and stability in safflower for cultivation in drought prone regions through appropriate selection methods.

\section{ACKNOWLEDGMENT}

The authors would like to thank Research Institute for Biotechnology and Bioengineering, Isfahan University of Technology, Isfahan, Iran. Research Center, Isfahan, Iran, is also acknowledged for their financial support as a research project number \# 97/ 70649.

\section{REFERENCES}

Abdolshahi, R., Safarian, A., Nazari, M., Pourseyedi, S., Mohamadi-Nejad, G. (2013). Screening drought-tolerant genotypes in bread wheat (Triticum aestivum L.) using different multivariate methods. Archives of Agronomy and Soil Science, 59(5), 685-704. https://doi.org/10.1080/03650340. 2012.667080
Anjum, S.H.A., Ashraf U., Zohaib A, Tanverr M., Naeem M., Iftikhar A, Tabassum T., Nazir U. (2017). Growth and developmental responses of crop plants under drought stress: a review. Zemdirbyste-Agriculture, 104(3), 267-276. https:// doi.org/10.13080/z-a.2017.104.034

Ashraf, M. (2010). Inducing drought tolerance in plants: Recent advances. Biotechnology Advances, 28,169-183. https://doi. org/10.1016/j.biotechadv.2009.11.005

Bahrami, F., Arzani, A., Karimi, V. (2014). Evaluation of yieldbased drought tolerance indices for screening safflower genotypes. Agronomy Journal, 106(4), 1219-1224. https:// doi.org/10.2134/agronj13.0387

Basu, S., Ramegowda, V., Pereira, A. (2016). Plant adaptation to drought stress. F1000 Research, 5, 1554. https://doi. org/10.12688/f1000research.7678.1

Blum, A. (2018). Plant Breeding for Stress Environments. CRC press, 231 pp. https://doi.org/10.1201/9781351075718

Clarke, T.C., Parkin, G.W., Ferre, T.P.A. (2008). Soil water content. In: Carter MR, Gregorich EG, editors. Soil sampling and methods of analysis. Pinawa: Canadian Society of Soil Science.

Ebrahimiyan, M., Majidi, M.M., Mirlohi, A., Gheysari, M. (2012). Drought-tolerance indices in a tall fescue population and its polycross progenies. Crop and Pasture Science, 63(4), 360-369. https://doi.org/10.1071/CP11279

FAOSTAT (2016). http://faostat.fao.org.

Fernandez, G.C.J. (1992). Effective selection criteria for assessing plant stress tolerance. In: C.G. Kuo, editor, Adaptation of Food Crops to Temperature and Water Stress: Proceedings of an International Symposium, Taiwan. 13-18 Aug. 1992. Asian Vegetable Res. and Dev. Ctr., Shanhua, Tainan, Taiwan. p. 257-270.

Fischer, R.A., Maurer, R. (1978). Drought resistance in spring wheat cultivars: 1. Grain yield response. Australian Journal of Agricultural Research, 29, 897-912. https://doi. org/10.1071/AR9780897

Gavuzzi, P., Rizza, F., Palumbo, M., Campaline, R.G., Ricciardi, G.L., Borghi, B. (1997). Evaluation of field and laboratory predictors of drought and heat tolerance in winter cereals. Plant Science, 77, 523-531. https://doi.org/10.4141/P96-130

Gholinezhad, E., Darvishzadeh, R., Bernousi, I. (2014). Evaluation of drought tolerance indices for selection of confectionery sunflower (Helianthus anuus L.) landraces under various environmental conditions. Notulae Botanicae Horti Agrobotanici Cluj-Napoca, 42(1), 187-201. https://doi. org/10.15835/nbha4219394

Golabadi, M., Arzani, A., Mirmohammadi Maibody, S.A.M. (2006). Assessment of drought tolerance in segregating populations in durum wheat. African Journal of Agricultural Research, 5, 162-171.

Golkar, P., Karimi S. (2019). Safflower (Carthamus tinctorius L.) Breeding. Edited by: Al-Khayri, J.M., Jain, S.M. and Johnson, D.V., In: Advances in Plant Breeding Strategies: Industrial and Food Crops. Springer. Pub. https://doi. org/10.1007/978-3-030-23265-8_14

Guttieri, M.J., Stark, J.C., Brien, K., Souza, E. (2001). Relative sensitivity of spring wheat grain yield and quality parameters to moisture deficit. Crop Science, 41, 327-335. https:// doi.org/10.2135/cropsci2001.412327x 
Hao, Z.F., Li, X.H., Su, Z.J., Xie, C.X., Li, M.S., Liang, X.L., Weng, J.F., Zhang, D.G, Li, L., Zhang, S.H. (2011). A proposed selection criterion for drought resistance across multiple environments in maize. Breeding Science, 61(2), 101108. https://doi.org/10.1270/jsbbs.61.101

Hussain, M.I., Lyra, D.A., Farooq, M., Nikoloudakis, N., Khalid N. (2016). Salt and drought stresses in safflower: a review. Agronomy and Sustainable Development, 36(1), p.4. https:// doi.org/10.1007/s13593-015-0344-8

Ilker, E., Tatar, O., Aykut Tonk, F., Tosun, M., Turk, J. (2011). Determination of tolerance level of some wheat genotypes to post-anthesis drought. Turkish Journal of Field Crops, 16(1), 59-63.

Khalili, M., Naghavi, M.R., Pour Aboughadareh, A.R., Talebzadeh, J. (2012). Evaluating of drought stress tolerance based on selection indices in spring canola cultivars (Brassica napus L.). Journal of Agricultural Science and Technology, 4(11), 78-85. https://doi.org/10.5539/jas.v4n11p78

Kirigwi, F.M., Van Ginkel, M., Trethowan, R., Seaes, R.G., Rajaram, S., Paulsen, G.M. (2004). Evaluation of selection strategies for wheat adaptation across water regimes. Euphytica, 135. https://doi.org/10.1023/ B:EUPH.0000013375.66104.04

Lan, J. (1998). Comparison of evaluating methods for agronomic drought resistance in crops. Acta Agriculturae Boreali-occidentalis Sinica, 7, 85-87.

Mirzahashemi, M., Golkar, P. and Mohamadinejad, G. (2014). Gene effects for agronomic traits in safflower (Carthamus tinctorius L.) under drought stress. Ethno-Pharmaceutical Products, 1(1), 23-28.

Mohammadi, M., Karimizadeh, R. and Abdipour, M. (2011). Evaluation of drought tolerance in bread wheat genotypes under dryland and supplemental irrigation conditions. Australian Journal of Crop Science, 5(4), 487-493.

Naghavi, M.R., Aboughadareh, A.P., Khalili, M. (2013). Evaluation of drought tolerance indices for screening some of corn (Zea mays L.) cultivars under environmental conditions. Notulae Scientia Biologicae, 5(3), 388-393. https://doi. org/10.15835/nsb539049

Omidi, A.H., Khazaei, H., Monneveux, P. Stoddard, F. (2012).
Effect of cultivar and water regime on yield and yield components in safflower (Carthamus tinctorius L.). Turkish Journal of Field Crops, 17, 10-15.

R Core Team. (2008). R: A language and environment for statistical computing. R Foundation for Statistical Computing, Vienna, Austria.

Raman, A., Verulkar, S., Mandal, N., Variar, M., Shukla, V., Dwivedi, J., Singh, B., Singh, O., Swain, P., Mall, A., Robin, S. (2012). Drought yield index to select high yielding rice lines under different drought stress severities. Rice, 5(1), 31. https://doi.org/10.1186/1939-8433-5-31

Rauf, S., Al-Khayri, J.M., Zaharieva, M., Monneveux, P. and Khalil, F. (2016). Breeding strategies to enhance drought tolerance in crops. In Advances in plant breeding strategies: agronomic, abiotic and biotic stress traits (pp. 397-445). Springer, Cham. https://doi.org/10.1007/978-3-319-225180_11

Rizza, F., Badeckb, F.W., Cattivellia, L., Lidestric, O., Di Fonzoc, N., Stancaa, A.M. (2004). Use of a water stress index to identify barley genotypes adapted to rainfed and irrigated conditions. Crop Science, 44, 2127-2137. https://doi. org/10.2135/cropsci2004.2127

Rosielle, A.A., Hamblin, J. (1981). Theoretical aspects of selection for yield in stress and non-stress environments. Crop Science, 21, 43-46. https://doi.org/10.2135/cropsci1981.001 1183X002100060033x

Sio-Se Mardeh, A., Ahmadi, A., Poustini, K., Mohammadi, V. (2006). Evaluation of drought resistance indices under various environmental conditions. Field Crops Research, 98, 222 - 229. https://doi.org/10.1016/j.fcr.2006.02.001

Varshney, R.K., Tuberosa, R., Tardieu, F. (2018). Progress in understanding drought tolerance: from alleles to cropping systems. Journal of Experimental Botany, 69(13), 3175 3179. https://doi.org/10.1093/jxb/ery187

Vieira, R.A.; Rocha, R.; Scapim, C.A.; Amaral, A.T., Jr.; Vivas, M. (2016). Selection index based on the relative importance of traits and possibilities in breeding popcorn. Genetics and Molecular Research. 15, 1-10. https://doi.org/10.4238/ gmr.15027719 
Table supplementary 1: Characteristics of the 100 different genotypes of safflower used in this study

\begin{tabular}{|c|c|c|c|c|c|c|c|c|}
\hline $\begin{array}{l}\text { Genotype } \\
\text { code }\end{array}$ & $\begin{array}{l}\text { Genotype } \\
\text { name }\end{array}$ & $\begin{array}{l}\text { Geographical } \\
\text { origin }\end{array}$ & $\begin{array}{l}\text { Genotype } \\
\text { code }\end{array}$ & $\begin{array}{l}\text { Genotype } \\
\text { name }\end{array}$ & $\begin{array}{l}\text { Geographical } \\
\text { origin }\end{array}$ & $\begin{array}{l}\text { Genotype } \\
\text { code }\end{array}$ & $\begin{array}{l}\text { Genotype } \\
\text { name }\end{array}$ & $\begin{array}{l}\text { Geographical } \\
\text { origin }\end{array}$ \\
\hline G1 & $\mathrm{A} 2$ & Iran (Azerbayejan) & G34 & Car159 & Germany & G67 & Car64 & Slovakia \\
\hline G2 & Ac- Stirling & Canada & G35 & Car160 & Russia & G68 & Car67 & Germany \\
\hline G3 & AC-sunset & Canada & G36 & Car161 & Russia & G69 & Car68 & Germany \\
\hline G4 & Arak 2811 & Iran (Markazi) & G37 & Car169 & Hungary & G70 & Car70 & Lybyan \\
\hline G5 & $\mathrm{C} 111$ & Iran(Isfahan) & G38 & Car175 & India (Kusum) & G71 & Car72 & North Korea \\
\hline G6 & Car118 & India & G39 & Car181 & India & G72 & Car74 & North Korea \\
\hline G7 & Car 116 & India & G40 & Car188 & Poland & G73 & Car75 & North Korea \\
\hline G8 & Car 9 & Slovaki & G41 & Car19 & Poland & G74 & Car76 & North Korea \\
\hline G9 & Car100 & Italy & G42 & Car190 & Iran (Isfahan) & G75 & Car77 & North Korea \\
\hline G10 & Car106 & Spain & G43 & Car198 & Azerbaijan & G76 & Car78 & Hungary \\
\hline G11 & Car114 & India & G44 & Car199 & Korean republic & G77 & Car79 & Japan \\
\hline G12 & Car117 & Sudan (tozi) & G45 & Car200 & unknown & G78 & Car80 & North Korea \\
\hline G13 & K21 & Iran (Kordestan) & G46 & Car201 & Sudan & G79 & Car83 & Tajikistan \\
\hline G14 & Car124 & Pakistan & G47 & Car210 & Spain & G80 & Car86 & Tunisia \\
\hline G15 & Car125 & Russia & G48 & Car211 & Germany & G81 & Car87 & Romania \\
\hline G16 & Car126 & Belgium & G49 & Car214 & Poland & G82 & Car89 & Tunisia \\
\hline G17 & Car127 & Germany & G50 & Car215 & Germany & G83 & Car94 & Spain \\
\hline G18 & Car129 & Germany & G51 & Car216 & Germany & G84 & GE62918 & Germany \\
\hline G19 & Car130 & Morocco & G52 & Car217 & Germany & G85 & Gila & USA \\
\hline G20 & Car131 & Paraguay & G53 & Car218 & Germany & G86 & Hartman & USA \\
\hline G21 & Car132 & Germany & G54 & Car219 & Germany & G87 & IL111 & $\begin{array}{l}\text { Iran (Aur- } \\
\text { oumieh) }\end{array}$ \\
\hline G22 & Car135 & Portugal & G55 & Car221 & Germany & G88 & Isf- 14 & Iran (Isfahan) \\
\hline G23 & Car137 & Pakistan & G56 & Car224 & Germany & G89 & Isf 28 & Iran(Isfahan) \\
\hline $\mathrm{G} 24$ & Car138 & Poland & G57 & Car226 & Germany & G90 & K21 & $\begin{array}{l}\text { Iran (Kord- } \\
\text { estan) }\end{array}$ \\
\hline G25 & Car146 & Egypt & G58 & Car227 & Germany & G91 & KMS 36 & Iran (karaj) \\
\hline G26 & Car147 & Pakistan & G59 & Car228 & Germany & G92 & Mex.17-45 & Mexico \\
\hline G27 & Car148 & Pakistan & G60 & Car230 & Germany & G93 & Mex.7-147 & Mexico \\
\hline G28 & Car151 & India & G61 & Car24 & Morocco & G94 & Mex.7-38 & Mexico \\
\hline G29 & Car152 & Iraq & G62 & Car37 & Sudan & G95 & Mex-13-216 & Mexico \\
\hline G30 & Car155 & Russia & G63 & Car42 & Sudan & G96 & Mex2-138 & Mexico \\
\hline G31 & Car156 & Pakistan & G64 & Car49 & Spain & G97 & Mex22-191 & Mexico \\
\hline G32 & Car157 & Morocco & G65 & Car55 & Poland & G98 & Mex6-97 & Mexico \\
\hline \multirow[t]{2}{*}{ G33 } & Car158 & Paraguay & G66 & Car56 & Nebraska 8 (USA) & G99 & PI 301055 & Turkey \\
\hline & & & & & & G100 & Saffire & Canada \\
\hline
\end{tabular}

